\title{
EVALUATION OF POLLUTANT LOADINGS IN HIGHWAY RUNOFF AND RELEVANT LEGISLATIVE FRAMEWORK
}

MALAMATARIS D. ${ }^{1, *}$

\author{
${ }^{1}$ Hydraulic Engineer, Postgraduate in Environmental Protection \\ and Sustainable Development, Aristotle University of Thessaloniki \\ Thessaloniki,Greece
}

Received: $15 / 02 / 2014$

Accepted: 19/06/2014

Available online: 20/10/2014 *to whom all correspondence should be addressed: e-mail: dimitrios.malamataris@gmail.com

\section{ABSTRACT}

Non-point sources pollution from highway runoff is among the most important reasons for surface and ground waters degradation. Atmospheric deposition, exhaust emissions, pavement wear and tire wear all have been found to be crucial pollutants in highway runoff. The most critical pollutants included in the runoff of interurban roads such as total suspended solids, heavy metals, chlorides and nutrients, together with the factors affecting their concentration are been investigated. Existing legislation about drainage and highway stormwater management in United States and European Union as well as the federal agencies of the United States which have the responsibility to regulate drainage and stormwater management are also presented. Water pollution concerns in the Unites States are mainly addressed through the Federal Water Pollution Control Act of 1972, known as the Clean Water Act. Provisions within the Clean Water Act require all states to implement regulations in order to reduce the pollutant mass loading prior to discharging into water recipients. In European Union the Water Framework Directive 2000/60/EC sets common goals for the water management and created an overall water policy for management at an international level.

Keywords: Environment, Water quality, Total Suspended Solids, Heavy metals, Chlorides, Nutrients, Legislative framework, Clean Water Act, Water Framework Directive

\section{Introduction}

Nowadays due to the water scarcity, the awareness for a sustainable use and protection of water resources has increased and so the interest for urban stormwater quality. Surface and ground waters are vulnerable to pollution because they are directly exposed to pollutants discharged from point and non-point source pollution. If left unchecked, highway runoff can damage the quality of receiving surface and ground waters causing significantly negative impacts on ecosystems. Highway runoff is the third most important source of groundwater contamination in Germany, after abandoned industrial sites and leaky sewers (Mull 1996). The major water quality problems associated with highways are the erosion runoff during construction and maintenance periods, the stormwater runoff during the life of the highway, accidents involving hazardous materials, and associated surface and groundwater contamination (Pitt, 2001). Highway runoff may cause adverse effects if no measures are taken for the removal of pollutants before the runoff reaches surface and ground waters. The most common contaminants in highway runoff are suspended solids, heavy metals, hydrocarbons and inorganic salts that accumulate on the road surface. The parameters most frequently monitored are sediments and metals due to their adverse impacts in aquatic biota (Yonge et al., 2002). 
Once these water resources are polluted, the water poses a threat in case of human consumption and the aquatic environment is harmed.

Regular highway operation, maintenance activities, the wear and tear of vehicles etc. result in the dropping of oil, grease, rust, hydrocarbons, rubber particles, and other solid materials on the highway surface. These materials are washed off the highway during rainfall events. Heavy metals present little groundwater contamination threat in case of surface infiltration systems are used in comparison to pesticides which are much more mobile (Mikkelsen et al., 1996a; Mikkelsen et al., 1996b).

Surface waters (streams, rivers, ponds, and lakes) are vulnerable due to the fact that they are exposed to contaminants released into the air and to discharges from point and non-point sources. However, they are easily accessible for assessment techniques. On the other hand, contamination of ground waters occurs gradually because contaminants percolate downward through the soil at slow rates, where the ground serves as a filter. In some case, where contaminants can also reach ground waters rather quickly through sinkholes in Karst areas (Smoot et al., 1997), ground waters are more sensitive to contamination because runoff passes with little if any infiltration through the soil. Contamination of ground waters is less visible than that of surface waters, and clean up is quite difficult and expensive. The presence of pollutants in surface or ground waters may interfere with the aquatic organisms living in it or from it (United States Department of Transportation, 2012).

Historically, highway drainage design was based absolutely on speedy removal of surface and subsurface waters taking no consideration the possible degradation of the environment. However, nowadays the awareness of highway runoff contaminants has attracted considerable attention to the study of their effects on receiving waters. The intention of highway runoff quantity management is to minimize excessive downstream flow which can be harmful to humans and properties. The basic principle is that any infrastructure should not increase the downstream flow above particular limits. A second goal of highway stormwater management is to maintain water quality above standards for human consumption and irrigating purposes (Delaware Department of Transportation, 2008).

In this paper, a study of highway runoff pollutants is carried out while the factors affecting the quality of highway runoff and the relevant legislative framework of United States and European Union are also been presented. The aim of the paper is to raise the scientific interest about the deterioration of water recipients due to the highway runoff.

\section{Highway runoff pollutants}

Pollutants that are found in highway runoff are total suspended solids, heavy metals, chlorides and nutrients. Effects of pollutants in rivers, streams and aquifers are different from those in lakes and reservoirs. In the first case, the most common problem is the suppression of aquatic life due to heavy metals which inhibit photosynthesis, transpiration and growth of aquatic species in contrast to case of lakes and reservoirs. The toxicity of waters depends on the physical and chemical form of the specific heavy metal and the current situation of the water body. Thus, a water body that contains a heavy metal in high concentration may in fact be less toxic than another one in which a different heavy metal is in less concentration.

Total suspended solids (TSS) are defined as the particulate matter retained by a glass fiber filter with $0.45 \mu \mathrm{m}$ pore size (American Public Health Association, 1995) with $99 \%$ of road-associated particles to be smaller than $20 \mu \mathrm{m}$ (Kayhanian, 2012c). Total suspended solids are the dominant pollutants from the urban highway while the peak concentration of them is occurred 20 min after the runoff started, a phenomenon which is called first flush (Ju Young et al., 2011). Suspended solids contain dust and debris and they are derived from congestion, maintenance work and usage of deicing agents. Load of suspended solids is not purely infectious as it contains organic elements. However, they play a significant role since they carry nutrients from fertilizers, atmospheric depositions and engine exhausts. Suspended solids are in a higher concentration in urban areas than in rural areas (Gupta et al., 1981). In 
case where they found in a high concentration in aquatic systems, a layer is created in water surface causing suffocation in lower layers and bottom.

Major sources of metals in road runoff include highway metal structures, worn tires, corroding car bodies and engine parts, brake shoes and linings and car exhausts. Heavy metals that are dangerous for natural recipients are cadmium $(\mathrm{Cd})$, lead $(\mathrm{Pb})$, copper $(\mathrm{Cu})$, zinc $(\mathrm{Zn})$, iron $(\mathrm{Fe})$, barium $(\mathrm{Ba})$, cesium (Cs), nickel $(\mathrm{Ni})$ and manganese $(\mathrm{Mn})$. Metals may be a problem when infiltrating stormwater using a rapid infiltration system (Crites and Ronald, 1985). One important consideration is the variation in metal concentrations within each continent and between continents. Values of copper, lead and zinc from North America are 20\%-30\% lower than the values from European countries and $50 \%$ lower than those from Asia (Kayhanian et al., 2012b). Cadmium, lead and copper are acutely toxic and the presence of lead-zinc and lead-copper metal combinations could cause synergistic toxic effects. In particular, European Union has added the cadmium in the list of dangerous substances with maximum established permissible limit at $5 \mathrm{mg} \mathrm{l}^{-1}$. This measure has caused its significant reduction usage in automotive industry. Lead is an almost insoluble element so its toxicity remains high in surface and ground waters. Human exposure to lead blunts a wide range of neurological functions and thus is treated as one of the most severe environmental health threats. However, it has been observed that the concentrations of total lead after the year 2000 are generally remained below $100 \mathrm{mg} \mathrm{l}^{-1}$ (Kayhanian, 2012a). Copper can threat plants in high concentrations while zinc is derived from various sources such as tires, brakes and deicing salts and can be easily dissolved. Copper and zinc are toxic to fishes even in low concentrations. According to the United States Environmental Protection Agency (EPA), upper values of some heavy metals which are crucial for the protection of aquatic life in fresh waters are presented in Table 1 according to the total hardness of surface waters.

Table 1. Upper values of copper, lead and zinc in highway runoff according to EPA (Driscoll et al., 1990)

\begin{tabular}{cccc}
\hline \multirow{2}{*}{$\begin{array}{c}\text { Total hardness of surface waters } \\
\text { (ppm) }\end{array}$} & Copper & Lead & Zinc \\
\cline { 2 - 4 } & 0,009 & 0,034 & 0,181 \\
\hline 50 & 0,011 & 0,043 & 0,210 \\
\hline 60 & 0,014 & 0,061 & 0,267 \\
\hline 80 & 0,018 & 0,082 & 0,321 \\
\hline 100 & 0,021 & 0,103 & 0,374 \\
\hline 120 & 0,024 & 0,125 & 0,425 \\
\hline 140 & 0,028 & 0,149 & 0,475 \\
\hline 160 & 0,031 & 0,173 & 0,523 \\
\hline 180 & 0,034 & 0,197 & 0,571 \\
\hline 200 & 0,037 & 0,223 & 0,618 \\
\hline 220 & 0,040 & 0,249 & 0,664 \\
\hline 240 & 0,044 & 0,276 & 0,710 \\
\hline 260 & 0,047 & 0,303 & 0,755 \\
\hline 280 & 0,050 & 0,331 & 0,800
\end{tabular}

Moreover, iron plays a dual role in natural recipients (Washington State Department of Transportation 2007). Due to its molecular structure and high electrical charge it can absorb dissolved heavy metal ions. On the other hand, it can be dangerous for the environment if it is found in high concentrations. Finally, barium, cesium, nickel and manganese cause certainly much lower impacts on water bodies than the other heavy metals.

Another constituent of concern in roadway runoff is chloride which include sodium chloride $(\mathrm{NaCl})$ and magnesium chloride $\left(\mathrm{MgCl}_{2}\right)$. The impact of chloride on the environment is an important environmental issue because the increase in salinity of freshwaters causes a variety of negative effects on aquatic and terrestrial ecosystems (Bartlett et al., 2012). Chlorides appear in high concentrations during winter because of throwing salt on rural roads. Road salt usage in the United States has been rising steadily, and at present is estimated to be 18 million $t_{\text {year }}^{-1}$ (Corsi et al., 2010). Surface waters are not as 
vulnerable to chloride as ground waters because of the growing turbulence that reduces the concentration of chloride.

Nutrients are also a constituent of concern in roadway runoff and they include nitrates $\left(\mathrm{NO}_{3}{ }^{-}\right)$, nitrites $\left(\mathrm{NO}_{2}{ }^{-}\right)$, ammonium $\left(\mathrm{NH}_{4}{ }^{+}\right)$, total Kjehldal nitrogen (TKN), total nitrogen (TN), phosphate $\left(\mathrm{PO}_{4}{ }^{3-}\right)$ and total phosphorus (TP). Total nitrogen and total phosphorus could create adverse conditions in the environment, such as turbidity, odor, and low concentrations of dissolved oxygen if found in high concentrations. Nitrogen and phosphorus species found in road runoff may be related to both traffic and non-traffic sources. In particular, sources of total nitrogen are fertilizers, feed lots, industrial cleaning operations, animal excrement, and combustion of fuels while fertilizers, tree leaves, industrial wastes, lubricants and detergents are sources of phosphorus. However, the contribution of total nitrogen and total phosphorus from traffic-related sources in runoff is less significant than that from natural sources (Kayhanian and Paytan 2011).

\section{Factors affecting the quality of highway runoff}

A wide variety of factors influence the chemical composition of highway runoff, including climatic variables, such as intensity, frequency and duration of precipitation; temperature; solar radiation; and anthropogenic factors such as traffic volume, road design and maintenance, road structures and appurtenances (e.g. guardrails, signs) (Mayer et al., 2011).

Table 2. Factors associating with the quality of runoff in highways.

\begin{tabular}{|c|c|c|c|c|c|c|}
\hline Pollutants & $\begin{array}{l}\text { Rainfall } \\
\text { duration }\end{array}$ & $\begin{array}{c}\text { Rainfall } \\
\text { intensity }\end{array}$ & $\begin{array}{l}\text { Rainfall } \\
\text { volume }\end{array}$ & $\begin{array}{l}\text { Antecedent } \\
\text { dry period } \\
\text { length }\end{array}$ & $\begin{array}{l}\text { Traffic } \\
\text { volume } \\
\text { during } \\
\text { rainfall }\end{array}$ & $\begin{array}{l}\text { Antece-dent } \\
\text { traffic count }\end{array}$ \\
\hline $\begin{array}{c}\text { Chemical Oxygen } \\
\text { Demand (COD) }\end{array}$ & + & + & + & + & & + \\
\hline $\begin{array}{c}\text { Biochemical } \\
\text { Oxygen Demand } \\
\left(\mathrm{BOD}_{5}\right)\end{array}$ & & + & + & + & + & \\
\hline $\begin{array}{l}\text { Total Suspended } \\
\text { Solids (TSS) }\end{array}$ & & + & + & + & + & \\
\hline $\begin{array}{l}\text { Total Nitrogen } \\
\text { (TN) }\end{array}$ & & + & + & & & + \\
\hline $\begin{array}{c}\text { Total Phosphorus } \\
\text { (TP) }\end{array}$ & + & + & + & + & & + \\
\hline Zinc $(Z n)$ & + & & + & + & & + \\
\hline Lead (Pb) & & + & + & + & + & \\
\hline Copper (Cu) & + & & + & + & + & \\
\hline Iron (Fe) & & + & + & + & & \\
\hline Petroleum, oil & & & + & & + & \\
\hline
\end{tabular}

Pollutants build up over time on road surfaces if they are not removed from the highways (by either sweeping/cleaning or rainfall event). However, unlike point source pollution, stormwater has an irregular pattern with a variability of pollutants concentrations between successive runoff events because of the random nature of rainfall (Vieira, 2013). The time between successive rainfall events is 
known as the antecedent dry period. Rainfall intensity may exert a strong impact on the type and amount of pollutants in runoff. Particulate pollutants are easily mobilized and transported by highintensity storms. Generally, higher rainfall intensity events and longer antecedent dry periods are responsible for greater contaminant loads in runoff (Marsalek et al., 1999). The concentrations of runoff pollutants are greater during rainfall with low volume because highway runoff pollutants cannot be diluted efficiently. The accumulation of iron, lead and zinc is a linear function of antecedent dry period and in particular a short antecedent dry period will result in lower pollutant loads. Moreover, there is a positive relationship between antecedent dry period length and event mean concentrations of total suspended solids, chemical oxygen demand (COD) and total nitrogen at a significance level of 0.001 (Bian and Cheng, 2011). Traffic volume plays a significant role on the chemical composition of highway runoff only in case of roads with traffic volume over 30 thousand vehicles per day. This trend is applied in Total Suspended Solids and most of the metal concentrations, except for zinc. Finally, the material of road surface (asphalt or concrete) has minimum impact on the quality of runoff. Factors which affect the quality of highway runoff are presented in Table 2.

\section{Drainage and highway stormwater management}

Appropriate drainage is fundamental in the design of highways since it affects the highway's serviceability and usable life. Managing highway runoff involves designing systems to address stormwater quantity and quality. Drainage design consists of collecting, transporting and removing stormwater from the highway surface. The regulatory environment related to drainage design is taking into consideration a lot of factors such as the flood insurance of highways, the water pollution management, the protection of fish and wildlife etc.

\subsection{United States legislation about drainage and highway stormwater management}

In the United States federal agencies formulate the legislation that regulates drainage and stormwater management. In particular, (a) The United States Department of Transportation (USDOT or DOT) was established by an act of United States Congress on 15 October 1966 and nowadays it consists of the Office of the Secretary and eleven Operating Administrations. It is the primary agency in the federal government and its mission is to shape, organize and promote policies and programs that will boost the safety and sufficiency of the transportation services leading to a dynamic and stable national transportation system. (b) The Federal Highway Administration (FHWA) was created on 15 October 1996 and its main role is to oversee funds used for constructing and maintaining the United States National Highway System ensuring that standards for contract administration and construction standards are adhered to. Also, in certain cases the FHWA provides highway design and construction services to other agencies. (c) The Federal Motor Carrier Safety Administration (FMCSA) was established on 1 January 2005. Its primary role is the trucking industry in the United States and in certain the improvement in the safety of commercial motor vehicles. On 1 March 2004 it published an Order on Agency procedures for achieving the National Environmental Policy Act of 1969 (NEPA) also promoting FMCSA agenda that integrates environmental protection aspects into informed decision making while satisfying conformity with NEPA. (d) The Office of Inspector General for the Department of Transportation (OIG) which is created by the Inspector General Act of 1978. The Inspector General for the Department of Transportation is responsible for achieving a safe, efficient, and effective transportation system. (e) The United States Secretary of Transportation is the head of the United States Department of Transportation. The secretary of Transportation oversees eleven agencies and its main responsibility is to develop and coordinate programs that will provide an efficient national transportation system taking into consideration the needs and environmental protection. (f) The Pipeline and Hazardous Materials Safety Administration (PHMSA) was created on 30 November 2004 and it is responsible for developing the legislation for the safe and environmentally sound operation of pipelines and hazardous materials transportation. The Office of Hazardous Materials Safety (OHMS) is the federal authority for the transportation of hazardous materials. The safety insurance in the transportation of these materials is a 
crucial subject cause in case of an accident near water bodies, the degradation in the quality of water is tremendous.

Some of the most significant federal laws related to highway drainage, water quality and environmental protection are: (a) The Federal-Aid Highway Act of 1950 (Public Law 81-769) referred the need to hold public hearings for projects bypassing cities or towns. (b) The National Environmental Policy Act of 1970 (NEPA) declared and promoted the appropriate national policies, goals and measures for environmental protection. (c) The Federal Water Pollution Control Act of 1972 (Clean Water Act) was the principal federal law in the United States regulating subjects about water pollution and ensuring that surface waters would meet the standards for water consumption. Programs that address polluted highway runoff according to this regulation are carried out at federal, state and local levels. Up to 2006, regulations were applicable only to communities with a population of 100,000 or more, but afterwards the discharge regulation has been applied to all communities with a population of 10,000 or more (United States Environmental Protection Agency 2011). (d) The Federal-Aid Highway Act of 1973 (Public Law 93-87) was signed on 13 August 1973 and its main responsibilities were the funding provision for urban and rural primary and secondary roads and also for the highway safety improvement. (e) The Safe Drinking Water Act of 1974 (SDWA) set standards for drinking water quality in order to protect public health. It also protected the water sources: lakes, rivers, reservoirs etc. (f) The Surface Transportation Assistance Act of 1982 (Public Law 97-424) was an extensive policy act of the United States Federal Government to deal with problems about the surface transportation infrastructure. (g) The intermodal Surface Transportation Efficiency Act of 1991 (Public Law 102-240) was the first United States federal regulation in the post-interstate highway system era. (h) The Transportation Equity Act of 1998 for the $21^{\text {st }}$ Century (Public Law 105-178) referred to environmental protection and to the improvement in the quality of life for the years 1998-2003. (i) The Safe, Accountable, Flexible, Efficient Transportation Equity Act of 2005 (Public Law 109-59) aimed to enhance and maintain the surface transportation infrastructure in the United States. (j) The Moving Ahead for Progress in the $21^{\text {st }}$ Century Act of 2012 (Public Law 112-141) was a funding bill to govern federal surface transportation spending (Delaware Department of Transportation, 2008).

\subsection{European Union legislation about drainage and highway stormwater management}

Management of the quality and quantity of runoff from highways has long been a considerable concern of many countries in the European Union, particularly those with traffic control problems. The highway runoff and water environment generally are regulated by a number of European Union regulations, comprising but not limited to: (a) The Directive 76/464/EC of 4 May 1976 regulates the degradation of the aquatic environment caused by hazardous substances and in particular the inland surface waters, territorial waters, inland coastal waters and ground water. (b) The Council Directive 91/271/EC concerning urban waste water treatment was published on 21 May 1991 and its objective is to protect the environment from the conflicting effects of urban waste water discharges. (c) The Council Directive 91/676/EC concerning the protection of waters against pollution caused by nitrates from agricultural sources and preventing further such pollution was adopted on 12 December 1991. Each member country shall establish a code of good agricultural practices. (d) The Water Framework Directive 2000/60/EC was published on 22 December 2000 and it established a framework for a sustainable water management of water resources. Up to 2000, most European countries had their own individual water quality regulations. The WFD sets common approaches in 27 member countries for the water management and in particular, it aims for good ecological and chemical status for all ground and surface waters in the European Union by the end of 2015. (e) The Freshwater Fish Directive 2006/44/EC was adopted on 6 September 2006 and it refers to the quality of fresh waters in order to maintain or improve water quality and to support fish life. Each member of the EU should designate the fresh waters which are appropriate for fish-breeding. 


\section{Conclusions}

Highway runoff quality is an issue with major environmental, economic and social implications. Insurance that road runoff would not present risks to the environment or human health is mandatory according to legislation of each country. In the design of highway drainage systems, highway agencies and organizations, apart from the hydraulic considerations, should take water quality considerations into account cause the degradation in the quality of surface and ground waters could be harmful in case of human consumption.

Pollution prevention efforts and management of urban stormwater runoff are often achieved by including low impact development practices, which are decentralized methods for drainage and stormwater management that include vegetation swales, filter strips, infiltration basins and trenches, porous pavements, and rain and roof gardens, among others. The main principle of these practices is the focus on prevention rather than mitigation by managing rainfall close to the source. When designed and practiced appropriately, low impact development practices can eliminate the need for construction of conventional treatment methods and will also eliminate the monitoring cost.

A great progress has been made on a wide range of monitoring issues of highway runoff. However, there is a key challenge that once resolved, can benefit all global communities. Specifically, there is a need for internationally common numerical limits for stormwater runoff in order drainage and stormwater management to be under universal legislation.

Finally, observatories should be established in highways for measuring environmental indicators. Crossing with surface waters is one of the most crucial indicators especially in case of surface and ground waters nearby highways that are used for human consumption or irrigation. The results are proposed to be compared among highway agencies from several countries and so local governments would be able to develop an effective control strategy of reducing stormwater micro-pollutants in the receiving waters in order to meet new requirements.

\section{References}

American Public Health Association, American Water Works Association and Water Pollution Control Federation (1995), Standard Methods for the Examination of Water and Wastewater, 17th edition, Washington D.C.

Bartlett, A., Rochfort, Q., Brown, L. and Marsalek, J. (2012), Causes of toxicity to Hyalella azteca in a stormwater management facility receiving highway runoff and snowmelt, Part II: Salts, nutrients, and water quality.

Bian, B. and Cheng, X.J. (2011), Quality characterization and impact assessment of urban runoff in a medium size city of China, 5th International Conference on Bioinformatics and Biomedical Engineering (iCBBE), Wuhan, China.

Corsi, SR., Graczyk, DJ., Geis, SW., Booth, NL. and Richards, KD. (2010), A fresh look at road salt: aquatic toxicity and water-quality impacts on local, regional, and national scales, Environmental Science and Technology; 44: 7376-82.

Crites, Ronald W. (1985), Micropollutant Removal in Rapid Infiltration, In: Artificial Recharge of Groundwater, Edited by Takashi Asano, Butterworth Publishers, Boston, 579-608.

Delaware Department of Transportation (2008) Road Design Manual. Chapter 6: Highway Drainage and Stormwater Management, State of Delaware, United States of America.

Driscoll, E., Shelley, P., Strecker, E. (1990), Pollutant Loadings and Impacts from Highway Stormwater Runoff, Volume I: Design Procedure, Federal Highway Administration, Washington.

Gupta, M. K., Agnew, R. W., Gruber, D., and Kreutzberger, W. (1981), Constituents of highway runoff. Volume IV: Characteristics of runoff from operating highways, Res. Rep. FHWA/RD-81/045, Prepared for Fed. Hwy. Admen., Washington, DC.

Ju Young, L., Hyoungjun, K., Youngjin, K. and Moo Young, H. (2011), Characteristics of the event mean concentration (EMC) from rainfall runoff on an urban highway, Environmental Pollution;159, 884-888.

Kayhanian, M., Paytan, A. (2011), Isotopic fingerprinting approach for nutrient source identification, Proceedings of 10th Annual StormCon Conference, August 21-25, Anaheim, CA. 
Kayhanian, M. (2012a), Trend and concentrations of legacy lead (Pb) in highway runoff, Environmental Pollution, 169-177.

Kayhanian, M., Fruchtman, B., Gulliver J., Montanaro, C., Ranieri, E. and Wuertz, S. (2012b), Review of highway runoff characteristics: Comparative analysis and universal implications, Water Research, 46, 6609-6624.

Kayhanian, M., McKenzie, E.R., Leatherbarrow, J.E., Young, T.M. (2012c), Characteristics of road sediment fractionated particles captured from paved surfaces, surface run-off, Science of the total environment; 439, 172-186.

Marsalek, J., Rochfort, Q., Brownlee, B., Mayer, T. and Servos, M. (1999), An exploratory study of urban runoff toxicity, Water Science and Technology, 39 (12), 33-39.

Mayer, T., Rochfort, Q., Marsalek, J., Parrott, J., Servos, M., Baker, M., Mclnnis, R., Jurkovic, A. and Scott, I. (2011), Environmental characterization of surface runoff from three highway sites in Southern Ontario, Canada: Chemistry, Water Quality Research Journal of Canada, doi: 10.2166/wqrjc.2011.035.

Mikkelsen, P.S., H. Madsen, H. Rosgjerg, and P. Harremoës (1996a), Properties of extreme point rainfall III: Identification of spatial inter-site correlation structure, Atmospheric Research.

Mikkelsen, P.S., K. Arngjerg-Nielsen, and P. Harremoës (1996b), Consequences for established design practice from geographical variation of historical rainfall data, Proceedings of the 7th International Conference on Urban Storm Drainage, Hannover, Germany.

Mull, R. (1996), Water exchange between leaky sewers and aquifers, Proceedings of the 7th International Conference on Urban Storm Drainage. Hannover, Germany, Edited by F. Sieker and H-R. Verworn, IAHR/IAWQ. SuG-Verlagsgesellschaft, Hannover, Germany, 695-700.

Pitt R. (2001), Stormwater management for highway projects, Symposium on the pollution of water sources from road run-off, Tel Aviv University, Israel.

Smoot, J.L., Cox, C.D., and Turpin, A.M. (1997), Laboratory Testing of a System to Treat Highway Stormwater in Karst Areas, The Engineering Geology and Hydrogeology of Karst Terranes, Balkema, Rotterdam: Beck \& Stephenson.

United States Department of Transportation, Federal Highway Administration (2012), Is highway runoff a serious problem? FHWA Environmental Technology Brief, Last access January 2014, URL: http://www.fhwa.dot.gov/publications/research/infrastructure/structures/98079/runoff.cfm.

United States Environmental Protection Agency (2011), Stormwater Discharges from Municipal Separate Storm Sewer Systems (MS4s), USEPA stormwater program, Last update June 2011, URL: http://cfpub.epa.gov/npdes/stormwater/munic.cfm.

Vieira, R., Fernandes, J.N., Barbosa, A.E. (2013), Evaluation of the impacts of road runoff in a Mediterranean reservoir in Portugal, Environmental Monitoring and Assessment, 185, 7659-7673.

Washington State Department of Transportation (2007), Untreated Highway Runoff in Western Washington, prepared by Herrera Environmental Consultants, Inc.

Yonge, D., A. Hossain, M. Barber, S. Chen, and D. Griffin (2002), Wet Detention Pond Design for Highway Runoff Pollutant Control, National Cooperative Highway Research Program. 